\title{
Specific Weed Tolerance of Wheat (Triticum aestivum L.) Varieties - A Key to Non-chemical Weed Control
}

\author{
K. KASSAI, Z. SZENTPÉTERY, Z. HEGEDÜS and M. JOLÁNKAI
}

Szent István University, Institute of Crop Production, Gödöllő (Hungary)

\begin{abstract}
Varieties of field crops belonging to different genotypes show different responses to weed populations (COX \& JACKSON, 1949). Apart of extremities concerning weed canopy, there is a dynamic, naturally balanced coenosys including weeds and the crop produced in all fields. Weeds reduce crop yields as they compete with crops for essential sources of life (JOLÁNKAI, 1995). There are three major factors influencing the competition between field crops and weed populations: water utilization, nutrient uptake and the vegetative growth dynamics. The latter can be considered as a main characteristic of a coenosys, since any component of that which may have a different chance for growth will dominate and so obstruct both physically and physiologically its neighbouring plants (SPRAGUE, 1959; MAAS, 1970). In addition to these there is a wide range of other factors which may influence alterations of a coenosys (e.g. diseases, epidemics and gradations etc), however these are more occasional. Within field crop species there are significant varietal differences in weed tolerance (UBRIZSY, 1962; JOLÁNKAI et al., 1992, 1995).

In present research winter wheat varieties were examined under various agronomic conditions to determine weed tolerance characteristics.
\end{abstract}

\section{Methods}

In a three year herbicide provocation field trial at Nagygombos, Hungary (1995-1998), six wheat varieties representing different genotypes were tested under exposed and protected conditions on small plots with four replicates. Three types of herbicide treatments (fluroxipir, bromoxynil and dicamba ai.) were applied in comparison with untreated "weedy" and hand picked "weed proof" controls.

Correspondence to: Katalin M. KASSAI, Szent István University, Faculty of Agricultural and Environmental Sciences, Institute of Crop Production, H-2103 Gödöllö, Páter K. u. 1. Hungary. E-mail: kassaim@fau.gau.hu 
Weed populations were sorted into two major groups according to the level of their occurrence. The most frequent weed species forming canopies are listed in Table 1. Plant growth, yield components and grain yield of each experimental treatment were evaluated and weed tolerance of varieties was determined.

Table 1

Major weed species observed on the experimental plots

\begin{tabular}{|l|l|}
\hline High occurrence weed species & Low occurrence weed species \\
\hline Bilderdykia convolvulus & Fumaria officinalis \\
Viola arvensis & Stachys annua \\
Matricaria inodora & Adonis aestivalis \\
Sinapis alba & Lathyrus tuberosus \\
Stellaria media & Sonchus arvensis \\
Lactuca spp & Galium aparine \\
& Papaver rhoeas \\
& Capsella bursa-pastoris \\
& Chenopodium album \\
& Conium maculatum \\
& Lamium amplexicaule \\
& Thlaspi arvense \\
& Cannabis sativa \\
& Convolvulus arvensis \\
\hline
\end{tabular}

\section{Results and Conclusions}

The magnitude of weed populations has shown significant differences. All weed control treatments, including chemical and mechanical applications had an influence on weed development. Herbicide treatments had about fifty per cent, while mechanical applications had a nearly hundred per cent effect concerning weed reduction. The latter can be considered as a level of total weed extinction. High weed canopies were observed in the case of untreated controls only (Table 2).

Table 2

Effect of treatments on the number of weeds per plot sample square Nagygombos, 1996-1998

\begin{tabular}{|l|c|c|}
\hline \multicolumn{1}{|c|}{ Treatment } & Before treatment & After treatment \\
\hline Untreated control & 6.81 & 6.01 \\
Weed proof control & 6.51 & 0.12 \\
Herbicide applications mean & 6.72 & 3.34 \\
\hline
\end{tabular}


Yield values were affected by the experimental treatments. Yield reduction of wheat varieties in high weed canopies was calculated relative to yield values of handpicked weed proof controls. Wheat cultivars have shown a variety specific yield response. Figure 1 shows the magnitude of yield losses induced by high weed canopies.

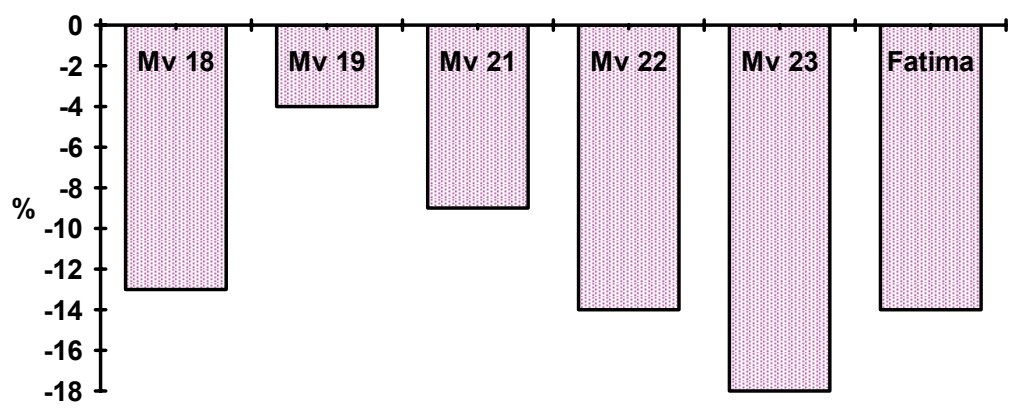

Figure 1

Yield reduction of wheat varieties in high weed canopies

The results obtained suggest varietal differences concerning weed tolerance. The extent of yield losses between varieties had a range from one- to four-fold, which is similar to the results of MAAS (1970). According to the present study Martonvásári 19 and Martonvásári 21 wheat varieties were proven to have the best weed tolerance abilities.

\section{Summary}

Six wheat varieties representing different genotypes were tested under exposed and protected conditions in a three year herbicide provocation field trial at Nagygombos, Hungary. Three types of herbicide treatments (fluroxipir, bromoxynil and dicamba ai.) were applied in comparison with untreated and mechanical treated controls. Weed populations were sorted into two major groups according to the level of their occurrence. The result of experimental treatments were evaluated and weed tolerance of varieties was determined. The magnitude of weed populations has shown significant differences. All weed control treatments, including chemical and mechanical applications, had an influence on weed development. Herbicide treatments had about fifty per cent, while mechanical applications had a nearly hundred per cent effect concerning weed reduction. The latter can be considered as a level of total weed extinction. High weed canopies were observed in the case of untreated controls only. Wheat cultivars have shown a variety specific yield response. The results ob- 
tained suggest varietal differences concerning weed tolerance. The extent of yield losses between wheat cultivars ranged from 4 to 18 per cent of grain yield. In the trial Martonvásári 19 and Martonvásári 21 wheat varieties were proven to have the best weed tolerance abilities.

Key words: weed tolerance, winter wheat, herbicide

This research was supported by the National Scientific Research Fund (OTKA) under Grant No. 29302.

\section{References}

CoX, J. F. \& JACKSON, L. E., 1949. Crop Management and Soil Conservation. John Wiley \& Sons. New York.

JolÁnKaI, M., 1995. Crop Production. Printorg Publishers. Budapest.

JOLÁNKAI, M. \& LÖVEI, I., 1992. Herbicide susceptibility of wheat varieties. (In Hungarian) Növényvédelmi Fórum., Keszthely.

JolÁNKAI, M. et al., 1995. Sustainability in agricultural development. In: Proc. $41^{\text {st }}$ EAAE Seminar, Gödöllő. 27-30.

MAAS, G., 1970. Über die Einfluß von Herbiziden auf die Standfestigkeit von Getreide. Zeitschrift für Pflanzenkrankheit. Sonderdruck 5.

Sprague, H. B., 1959. Grasslands. American Association for the Advancement of Science. Washington, D. C.

UBRIZsY, G., 1962. Chemical Weed Control. (In Hungarian) Mezőgazdasági Kiadó. Budapest. 